\title{
Special issue on the contributions of Gordon Tullock
}

March 2016

This issue of Constitutional Political Economy focuses on the work of Gordon Tullock, who died in November of 2014 at the age of 92.

A special memorial conference on his work was held at George Mason University in September of 2015, at which a series of distinguished scholars presented papers on Tullock's research and its influence on rent seeking, revolution, constitutional theory, law and economics, experimental economics, and philosophy of science. A subset of the papers presented at the conference appear in this volume. Others will appear later this year. The papers are not paeans to Tullock, but scholarly summaries and assessments of his contributions.

Tullock's contributions to constitutional political economy are somewhat underrecognized, because he did not use the standard constitutional vocabulary in his work. However, his comparative analysis of the institutions of political and legal systems clearly addresses issues at the core of the CPE research program. It is thus very appropriate that this major scholar's ideas be given serious attention by this journal. 